\title{
Gode biobanker for bedre helse
}

\author{
Norske biobanker er en forskningsressurs i verdensklasse. Vi har derfor forutsetninger \\ for å drive biobankrelatert forskning av høy internasjonal kvalitet, men potensialet er ikke tatt \\ godt nok ut. Et første skritt ville være å etablere et nasjonalt råd for biobankforskning som \\ foreslått i rapporten Gode biobanker - bedre helse.
}

\section{Wenche Reed}

wenche.reed@radiumhospitalet.no Roger Bjugn

Stabsenhet forskning og utvikling

Oslo universitetssykehus

Trondheimsveien 235

0514 Oslo

I april 2009 la regjeringen frem forskningsmeldingen Klima for forskning (1). Medisinsk og helsefaglig forskning er et av satsingsområdene. I meldingen påpekes sykehusenes ansvar for klinisk, pasientrettet forskning. Sykehusene har også en viktig rolle i translasjonsforskningen, dvs. forskning som resulterer i overføring av kunnskap mellom grunnforskning og klinisk forskning. Biobanker og tilhørende helseopplysninger er viktige verktøy i denne sammenheng.

\section{Biobanker}

Biobanker er samlinger av biologisk materiale, som regel med assosiert informasjon.
I Norge reguleres biobanker med humant biologisk materiale av behandlingsbiobankloven (2) og helseforskningsloven (3). Behandlingsbiobankloven dekker materiale som er «avgitt for medisinsk undersøkelse, diagnostikk og behandling», mens helseforskningsloven dekker materiale «som anvendes i et forskningsprosjekt eller skal anvendes til forskning». De største biobankene i Norge er de diagnostiske biobankene ved patologilaboratoriene. Årlig tas det nesten en million celle- og vevsprøver som lagres i disse biobankene (4). Humane forskningsbiobanker kan være knyttet til store befolkningsunders $ø$ kelser, som Helseundersøkelsen i Nord-Trøndelag (5) og Den norske mor og barn-undersøkelsen (6), eller til mindre forskningsprosjekter.

Bruk av humant biologisk materiale til forskning og utvikling av bedre behandlingstilbud anses som viktig. Samtidig har veksten $i$ antall biobanker kombinert med bruk av helseopplysninger og moderne genteknologiske teknikker reist flere kom- plekse etiske problemstillinger knyttet til personvern og samtykke (7).

\section{Styrking av forskningsinfrastruktur} I forskningsmeldingen omtales infrastruktur særskilt. Regjeringen bygger bl.a. på Norges forskningsråds rapport om nasjonal strategi for forskningsinfrastruktur (8). I meldingen tydeliggjøres ansvarsdelingen mellom forskningsinstitusjoner, Forskningsrådet og departementer. Institusjonene skal finansiere basisutstyr $(<2$ mill. kroner), Forskningsrådet skal finansiere nasjonal og internasjonal forskningsinfrastruktur (2-200 mill. kroner) mens Kunnskapsdepartementet eller sektordepartementer skal finansiere særlig kostbar forskningsinfrastruktur (> 200 mill. kroner).

Regjeringen vil øremerke 4 mrd. kroner til langsiktig finansiering av forskningsinfrastruktur. Midlene hentes fra avkastningen i Fondet for forskning og nyskaping (som ble etablert i 1999) fra 2010. Det vil gi en årlig bevilgning til forskningsinfra-

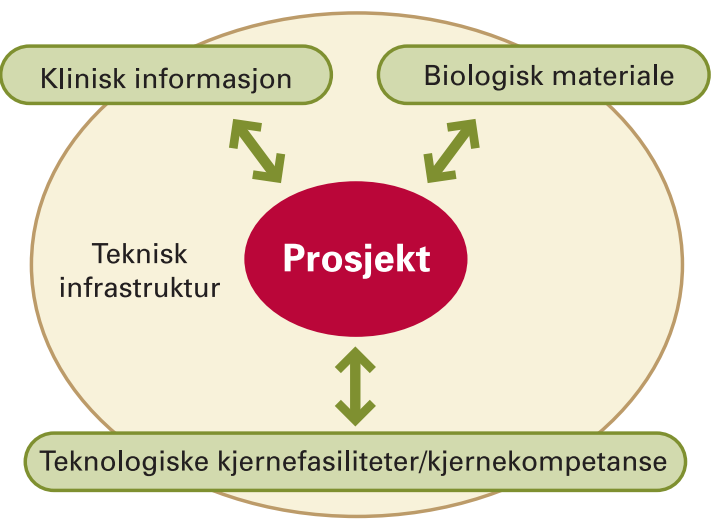

Figur 1 Sammenheng mellom biologisk materiale (biobank), helsedata, teknisk infrastruktur og forskning (10)

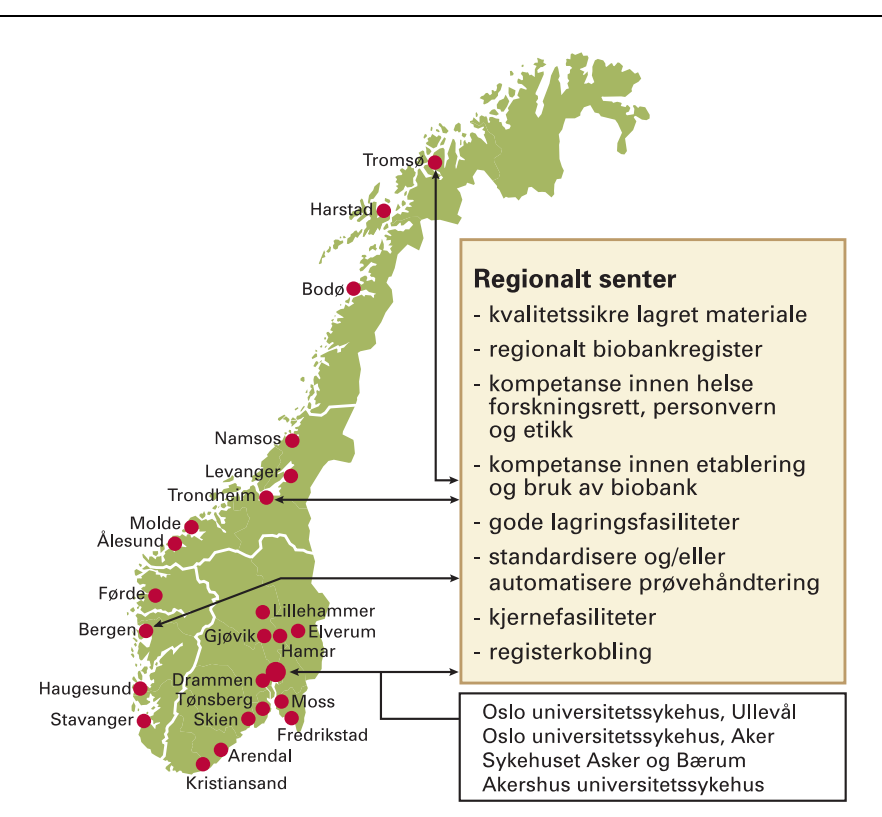

Figur 2 Potensielle oppgaver til regionale biobanksentre (10) 


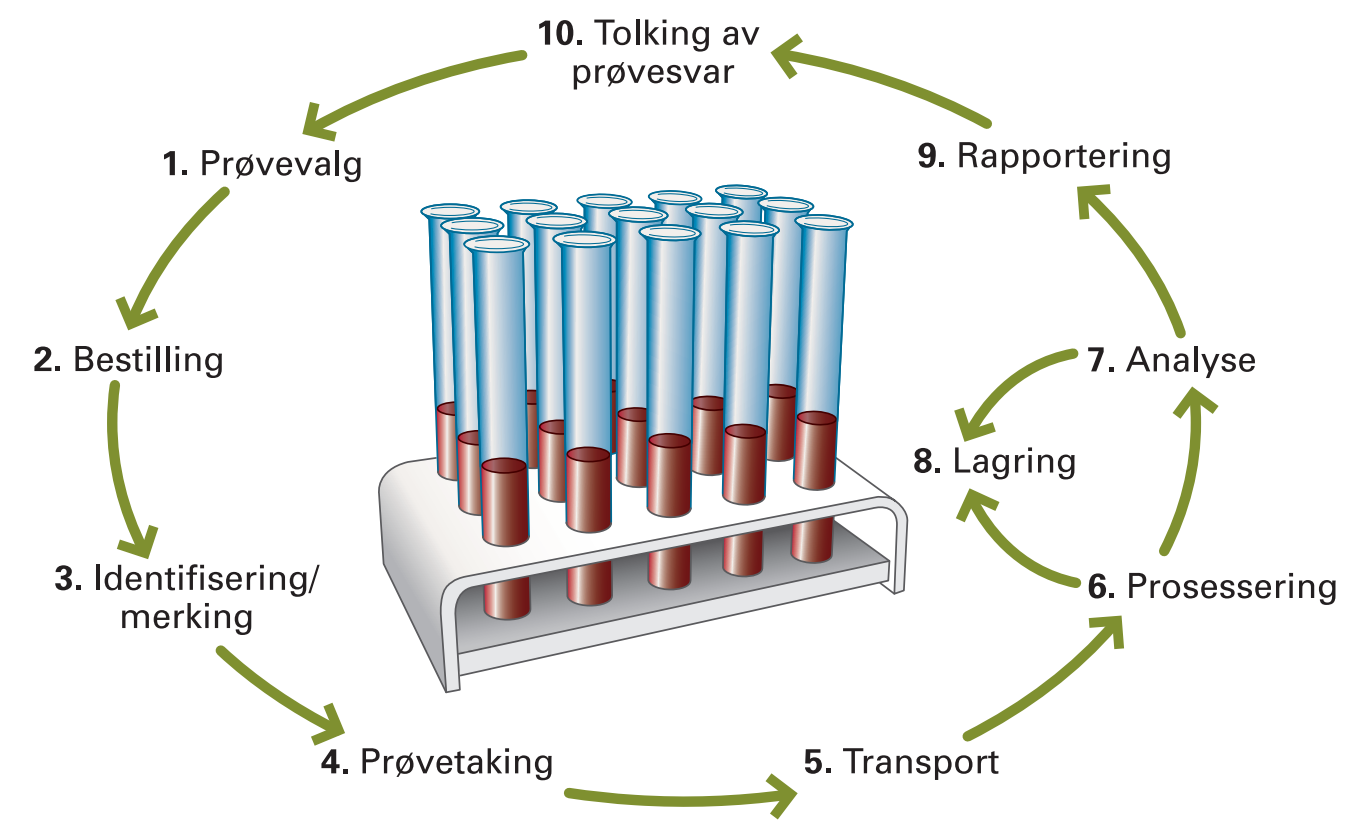

Figur 3 Prosesser knyttet til innsamling, håndtering, analyse og lagring av humant biologisk materiale, basert på rapport fra Universitetet i Oslo (11)

struktur på ca. 146 mill. kroner. Sett i lys av søknader for til sammen 6,8 mrd. kroner ved årets utlysning fra Forskningsrådet er regjeringens satsing beskjeden.

Nasjonal infrastruktur for biobanker I den forrige forskningsmeldingen sto det: «Den nasjonale satsningen på helseforskning skal for det første sikre en bedre utnyttelse av nasjonale fortrinn innenfor medisinsk og helsefaglig forskning. Blant annet skal infrastrukturen og tilgjengligheten rundt helseregistre og biobanker styrkes» (9).

I 2008 utga Norges forskningsråd rapporten Gode biobanker - bedre helse (10). Her står det at Norge har gode forutsetninger for å drive langsiktig epidemiologisk og klinisk forskning, og at norske biobanker representerer en forskningsressurs i verdensklasse. Selv om vi i Norge således skulle ha alle forutsetninger for å drive biobankrelatert forskning av høy internasjonal kvalitet, er ikke potensialet tatt godt nok ut. Manglende samspill mellom helseforetak, universiteter og institusjoner med ansvar for helseregistre, samt fravær av adekvat infrastruktur som fremmer et slikt samspill, er blant årsakene til dette. Kritiske faktorer for klinisk forskning og translasjonsforskning ble illustrert som vist i figur 1. Rapporten anbefalte at det etableres en langsiktig, nasjonal plattform for biobanker og helsedata til bruk i forskning. Blant foreslåtte tiltak var bl.a.:

- Etablering av nasjonalt råd for biobanker og helsedata

- Etablering av regionale sentre for biobanker og helsedata
- Etablering av nasjonal infrastruktur som sikrer et effektivt system for bruk og utveksling av biobankrelatert informasjon og helsedata

Blant foreslåtte oppgaver til nasjonalt råd var å utvikle felles nasjonale systemer for biobanker og helsedata for forskning, bidra til å utvikle felles retningslinjer for drift og tilgang til biobanker og helsedata samt være rådgivende overfor nasjonale forvaltningsorganer i saker som gjelder biobanker og helseregistre. Rådets hovedformål vil således være å fremme og støtte tilgjengligheten og utnyttelsen av biobanker for forskning. Det foreslås også at det nasjonale rådet koordinerer arbeidet med utvikling av lagrings- og sporingssystemer av prøver i biobanker. Et permanent råd kan organiseres under Nasjonal samarbeidsgruppe for medisinsk og helsefaglig forskning (NSG). Fordelen med en slik organisering er at denne nasjonale samarbeidsgruppen er en eksisterende organisasjon som omfatter alle offentlige institusjoner som har forskningsbiobanker, og som bør representeres i rådet.

Potensielle oppgaver til regionale biobanksentre er illustrert i figur 2 .

De største samlingene av humant biologisk materiale i Norge inngår i behandlingsbiobanker og diagnostiske biobanker ved sykehusene. I forskningsprosjekter vil materialet i forskningsbiobankene være innsamlet spesifikt for prosjekter eller kommer fra biobanker etablert i forbindelse med diagnostikk og behandling. $88 \%$ av medisinsk forskning skjer ved universitetssykehusene (1). Sykehusene bruker betydelige ressurser til drift av behandlingsrela- terte og diagnostiske biobanker, men fokus har vært individrettet diagnostikk og behandling - ikke forskning.

Verdien av biobankene øker i takt med metodeutviklingen. Det er allerede mulig å ekstrahere DNA fra materiale lagret i gamle parafinblokker, og det utredes nå om det også er mulig å utvinne mRNA av tilfredsstillende kvalitet fra de samme blokkene. I tillegg vil den vitenskapelige verdien av humant biologisk materiale, med tilhørende klinisk informasjon, øke med tiden, ettersom mange studier trenger en årelang observasjonstid etter analyse eller intervensjon. Ressursmessig er det hensiktsmessig om relevant innsamlet biologisk materiale kan oppbevares over lengre tidsperioder og gjøres tilgjengelig for mange forskere. Det store potensialet ligger således i å etablere en nasjonal infrastruktur som muliggjør bruk av dette materialet innen de rammene lovverket setter. Dette forutsetter en nasjonal enighet om en felles plattform. For å lykkes er det nødvendig med omforente retningslinjer for forskernes tilgang til biobankmaterialet, i tråd med intensjonen for innsamlingen og i tråd med de rammene lovverket og personvernet setter.

I biobankrapporten fra Forskningsrådet ble det anbefalt å utvikle et nasjonalt system for utveksling av biobankrelatert informasjon både innen og mellom de mest sentrale biobankene. I praksis betyr det etablering av sporingssystemer for biologisk materiale, datavarehusløsninger for klinisk informasjon og mekanismer for sikker elektronisk overføring av informasjon mellom forskningsorganisasjoner. 


\section{Styrking av biobankrelatert forskning}

Helse Sør-Øst omfatter ca. $55 \%$ av den norske befolkning, og Oslo universitetssykehus alene står for halvparten av forskningsaktiviteten ved sykehusene. Ved Oslo universitetssykehus omfatter omtrent halvparten av forskningsprosjektene biobanker.

I 2007 og 2009 ble det utarbeidet to rapporter om etablering av et regionalt biobanksenter (11). I den nyeste rapporten ble det påpekt at skal det endelige forskningsresultatet være av høy kvalitet, må alle prosesstrinn knyttet til håndtering av biologisk materiale (fig 3) være av tilsvarende kvalitet.

Utvalget foreslo at senteret bl.a. skal etablere regionale løsninger for sporingssystemer og datavarehus innen de enkelte helseforetakene og være regional fasilitet for håndtering og lagring $\mathrm{av}$ biologisk materiale. Utvalget påpekte at en vellykket regional funksjon baserer seg på samspill mellom de enkelte forskningsinstitusjonene i regionen og det regionale biobanksenteret.

Basert på de to rapportene er det nå nedsatt en gruppe som mer detaljert skal utrede kostnader knyttet til etablering av et slikt senter. I gruppen sitter representanter fra Helse Sør-Øst, Universitetet i Oslo og Nasjonalt folkehelseinstitutt.

Koordinert med det regionale arbeidet pågår et samarbeidsprosjekt mellom Akershus universitetssykehus, Oslo universitetssykehus og Sørlandet sykehus om hvordan man i praksis skal etablere sykehusomfattende sporingssystemer for biologisk materiale, og hvordan klinisk datavarehus kan etableres for å håndtere journalopplysninger. Konseptet man arbeider etter, har vært utarbeidet $i$ tett samarbeid med sykehusenes personvernombud og IKT-arkitekter. En føring er at det etableres et forvaltningssystem som skal styrke personvernet med henblikk på håndtering av personopplysninger.

\section{Blikk mot Europa}

European Strategy Forum on Research Infrastructures (ESFRI) ble etablert i 2002 og består av representanter fra EUs medlemsland og assosierte land. Forumets rolle er bl.a. å bidra til å etablere en overordnet strategi for utvikling av forskningsinfrastruktur i Europa. I 2006 publiserte ESFRI rapporten European roadmap for research infrastructures (12). I denne ble det foreslått å etablere et paneuropeisk nettverk for biobanker.

I Nederland bevilget regjeringen i 2007 35 mill. euro over fire år for å etablere prospektive forskningsbiobanker ved de åtte universitetssykehusene. De deltakende sykehusene må bidra med samme investeringsbeløp (13).

I Luxembourg har man nylig vedtatt å investere 140 mill. euro over fem år for å etablere en verdensledende forskningsbiobank med integrerte forskningsprogrammer (14).

Gjennom det Nationella Biobanksprogrammet (2002-07) samordnet Sverige de fleste av biobankene og utarbeidet felles kvalitetsstandarder for biobankvirksomhet. Det er også utarbeidet en nasjonal standard for pasientinformasjon som benyttes for innhenting av samtykke. I 2006 ble det oppnevnt et Nationellt biobanksråd som arbeider med en bedre ressursutnyttelse av biobankmateriale (15).
I Danmark har Statens Serum Institut nylig fătt 121 mill. danske kroner fra Videnskabsministeriet og Novo Nordisk Fonden for etablering av en nasjonal biobank (16).

Nå er det viktig at vi også i Norge kommer ut av startblokkene.

Oppgitte interessekonflikter: Ingen

Litteratur

1. St.meld. nr. 30 (2008-2009). Klima for forskning.

2. Behandlingsbiobankloven. Kap. 1. 21.2. Nr.12 2003

3. Helseforskningsloven. Kap. 1. 20.6. Nr. 442008

4. Norges offentlige utredninger. Biobanker - innhenting, oppbevaring, bruk og destruksjon av humant biologisk materiale. NOU 2001: 19

5. NTNU. Helseundersøkelsen i Nord-Trøndelag.www.ntnu.no/dmf/hunt (15.1.2010)

6. Folkehelseinstituttet. www. fhi.no (15.1.2010).

7. Elger BS, Caplan AL. Consent and anonymization in research involving biobanks. EMBO reports 2006; 7: 661-6.

8. Verktøy for forskning. Nasjonal strategi for forskningsinfrastruktur (2008-2017). Oslo: Norges forskningsråd, 2008.

9. St.meld. nr. 20 (2004-2005). Vilje til forskning

10. Gode biobanker - bedre helse. Oslo: Norges forskningsråd, 2008.

11. Universitetet i Oslo. Det medisinske fakultet. Regionalt biobanksenter. www.med.uio.no/shhu/ regionalt-ressurssenter/ressurssenter.xml (15.1.2010).

12. European Strategy Forum on Research Infrastructures. European roadmap for research infrastructures. Report 2006. Luxembourg: Office for Official Publications of the European Communities, 2006.

13. Parelsnoer Initiatief. www.parelsnoer.org (15.1.2010).

14. The Integrated Biobank of Luxembourg (IBBL). www.ibbl.lu (15.1.2010)

15. Biobanksverige. www.biobanksverige.se (15.1.2010).

16. Statens Serum Institut. www.ssi.dk (15.1.2010).

Manuskriptet ble mottatt 16.9. 2009 og godkjent 19.3. 2010. Medisinsk redaktør Trine B. Haugen. 